\title{
PERKEMBANGAN RUANG LINGKUP ANTROPOLOGI HUKUM
}

\author{
Nama Mahasiswa : Fauzia Amelia Putri \\ Email : fauziaameliaputri1893@gmail.com \\ No BP : 210003600063 \\ Kelas : $1 \mathrm{H} 2$ \\ Prodi : Antropologi \\ Perguruan Tinggi : Universitas Ekasakti
}

\section{A. PENDAHULUAN}

Antropologi sebagai disiplin ilmu terus berkembang, tidak hanya pada tataran teoritis tetapi juga sebagai ilmu terapan yang mampu memberikan masukan bagi para pembuat keputusan dalam menentukan kebijakan pembangunan. Di Indonesia, perkembangan antropologi sebagai disiplin ilmu yang dipelajari para mahasiswa di perguruan tinggi masih tergolong baru. Salah satu tokoh penting dalam perkembangan antropologi di Indonesia adalah Koentjaraningrat, sehingga dapat dikatakan bahwa ia merupakan bapak antropologi di Indonesia (Suparlan, 1988). Sebagai tokoh sentral di Indonesia, Koentjaraningrat telah meletakkan dasar-dasar antropologi Indonesia. Beberapa tugas yang berhasil diembannya adalah 1) mengembangkan prasarana akademis ilmu antropologi; 2) mempersiapkan dan membina tenaga-tenaga pengajar dan tenaga ahli di bidang antropologi; dan 3) mengembangkan bahan pendidikan untuk pembelajaran bidang antropologi (Masinambow, 1997). Sebagai disiplin ilmu, antropologi merupakan kajian yang multidisipliner yang berupaya mengkaji aspek manusia secara menyeluruh (holistik).

Secara historis, antropologi berkembang dari suatu deskripsi hasil-hasil laporan 
perjalanan para penjelajah dan penjajah tentang kehidupan manusia di daerah yang disinggahi para penjelajah, atau kehidupan salah satu suku bangsa yang tinggal di daerah jajahan. Deskripsi tersebut dikenal dengan nama etnografi. Dalam perjalanannya kemudian, antropologi berkembang sebagaimana keberadaannya sekarang baik di negara-negara Eropa Barat, Amerika maupun di Asia. Beberapa cabang antropologi yang dikenal secara luas saat ini adalah antropologi fisik atau biologi, antropologi sosial, dan antropologi budaya. Di sisi yang lain, antropologi juga merupakan bidang ilmu terapan sehingga hasil kajiannya dapat dimanfaatkan sebagai masukan dalam pengambilan keputusan untuk keperluan pembangunan, terutamadalam pembangunan sosial budaya, seperti antropologi pembangunan, antropologi kesehatan, antropologi ekonomi, dan sebagainya.

Adapun hal hal yang akan dibahas pada makalah ini adalah penegrtiaan/peranan mengembangkan prasarana akademis ilmu antropologi dalam ruang lingkup antropologi hukum,dan membina tenaga-tenaga pengajar dan tenaga ahli di bidang antropologi ruang lingkup antropologi hukum,dan bagaimana latar belakang dari ruang lingkup antropologi hukum itu terjadi.Serta bagaimana ruang lingkup itu bisa ada pada masa sekarang ini. pendidikan untuk pembelajaran bidang antropologi Nilai dalam ruang lingkup antropologi hukum. Kemudian, tujuan dari makalah ini adalah untuk memberikan gambaran tentang teori mengenai Peran, Status, Nilai, Norma, dan juga Budaya/kebudayaan dalam kaitannya dengan masyarakat sebagai sasaran ilmu Sosiologi, sebagai arahan agar saya sebagai mahasiswa dapat mengkorelasikan hubungan antara teori Peran, Status, Nilai, Norma dan Budaya/kebudayaan dalam kehidupan masyarakat di kehidupan yang nyata. 


\section{B. PEMBAHASAN}

\section{Pengertian Antropologi}

Sebelum Anda mempelajari lebih jauh tentang antropologi maka Anda terlebih dulu harus mengetahui pengertian dari antropologi. Nah, sekarang kita mulai dengan arti dari kata "Antropologi". Antropologi adalah sebuah ilmu yang mempelajari makhluk manusia (anthropos). Secara etimologi, antropologi berasal dari kata anthropos berarti manusia dan logos berarti ilmu. Dalam antropologi, manusia dipandang sebagai sesuatu yang kompleks dari segi fisik, emosi, sosial, dan kebudayaannya. Antropologi sering pula disebut sebagai ilmu tentang manusia dan kebudayaannya.

Antropologi mulai banyak dikenal orang sebagai sebuah ilmu setelah diselenggarakannya simposium pada tahun 1951 yang dihadiri oleh lebih dari 60 tokoh antropologi dari negara-negara di kawasan Ero-Amerika (hadir pula beberapa tokoh dari Uni Soviet). Simposium yang dikenal dengan sebutan International Symposium on Anthropology ini telah menjadi lembaran baru bagi antropologi, terutama terkait dengan publikasi beberapa hasil karya antropologi, seperti buku yang berjudul "Anthropology Today" yang di redaksi oleh A.R. Kroeber (1953), "An Appraisal of Anthropology Today" yang di redaksi oleh S. Tax, dkk. (1954), "Yearbook of Anthropology" yang diredaksi oleh W.L. Thomas Jr. (1955), dan "Current Anthropology" yang di redaksi oleh W.L. Thomas Jr. (1956). Setelah simposium ini, antropologi mulai berkembang di berbagai negara dengan berbagai tujuan penggunaannya. Di beberapa negara berkembang pemikiran-pemikiran antropologi mengarah pada kebutuhan pengembangan teoritis, sedangkan di wilayah yang lain antropologi berkembang dalam tataran fungsi praktisnya. Pengertian lainnya disampaikan oleh Harsojo dalam bukunya yang 
berjudul “Pengantar Antropologi” (1984). Menurut Harsojo, antropologi adalah ilmu pengetahuan yang mempelajari umat manusia sebagai makhluk masyarakat. Menurutnya, perhatian antropologi tertuju pada sifat khusus badani dan cara produksi, tradisi serta nilai-nilai yang akan membedakan cara pergaulan hidup yang satu dengan pergaulan hidup yang lainnya. Sementara itu Koentjaraningrat dalam bukunya yang berjudul “Pengantar Antropologi I " (1996) menjelaskan bahwa secara akademis, antropologi adalah sebuah ilmu tentang manusia pada umumnya dengan titik fokus kajian pada bentuk fisik, masyarakat dan kebudayaan manusia. Sedangkan secara praktis, antropologi merupakan sebuah ilmu yang mempelajari manusia dalam beragam masyarakat suku bangsa guna membangun masyarakat suku bangsa tersebut.

\section{Latar Belakang Lahirnya Antropologi Hukum}

Antropologi pada masa perkembangan awalnya tidak dapat dipisahkan dengan karya-karya para penulis yang mencatat gambaran kehidupan penduduk atau suku bangsa di luar Eropa. Pada saat itu, kehidupan penduduk di luar Eropa dipandang menarik oleh para penjelajah, para penjajah, atau para misionaris karena perbedaan cara hidup antara masyarakat Eropa dengan masyarakat di luar Eropa. Oleh karenanya, mereka bukan saja menulis tentang perjalanan atau yang terkait dengan tugasnya tetapi juga melengkapinya dengan deskripsi tentang tata cara kehidupan masyarakat yang mereka temui. Deskripsi ini kemudian dikenal dengan sebutan etnografi. Beberapa tulisan karya mereka akan dipaparkan pada uraian berikut. 
Tulisan Herodotus, seorang bangsa Yunani yang dikenal pula sebagai Bapak sejarah dan etnografi, mengenai bangsa Mesir merupakan tulisan etnografi yang paling kuno. Tulisantulisan etnografi pada masa awal masih bersifat subyektif, penuh dengan prasangka dan bersifat etnosentrisme. Etnosentrisme adalah sebuah pandangan atau sikap di mana suku bangsa sendiri dianggap lebih baik dan dijadikan ukuran dalam melihat baik buruknya karakter suku bangsa lainnya. Orang Yunani pada masa itu menganggap bahwa suku-suku bangsa selain orang Yunani seperti orang Mesir, Libia dan Persia termasuk ke dalam suku bangsa yang masih setengah liar dan belum beradab. Pandangan seperti ini juga tersirat dalam tulisan Heredotus yang mendeskripsikan suku bangsa Mesir tersebut.Pada jaman Romawi kuno terdapat pula beberapa hasil karya etnografi mengenai kehidupan suku bangsa Germania dan Galia yang ditulis oleh Tacitus dan Caesar. Sebagai seorang perwira yang memimpin perjalanan tentaranya sampai ke Eropa Barat, Caesar menulis etnografinya secara sistematis seperti halnya bentuk laporan seorang perwira. Sedangkan Tacitus menulis etnografinya dengan gaya bahasa yang mengungkap perasaan dan kegalauannya tentang kehidupan yang terdapat di ibukota kerajaan Roma. Pencatat etnografi yang cukup terkenal adalah Marco Polo (1254-1323). la mengembara dengan keluarga besarnya ke daerah Asia Timur dan sempat menetap di istana Khu Bilai Khan. Di sini ia melihat beberapa kebiasaan yang dianggapnya aneh, yaitu penggunaan uang yang terbuat dari kertas dan diberi cap serta ditandatangani di mana uang tersebut mempunyai bermacammacam nilai. Marco Polo juga pernah singgah di daratan Indonesia (yang diketahui dari tulisannya), di mana ia pernah singgah di beberapa pelabuhan dari semenanjung Malaya hingga menelusuri Pulau Sumatra, di antaranya adalah singgah ke di pelabuhan Perlec (dalam bahasa Aceh) atau Peureula atau Perlak (dalam bahasa Melayu). Marco Polo menceritakan kehidupan di 
kota pelabuhan ini di mana pedagang dari India dan penduduk pribuminya menganut agama Islam sedangkan penduduk yang ada di pedalaman masih mengerjakan hal-hal yang haram.

Tulisan etnografi yang dianggap lebih baik dan obyektif justru adalah buah tangan dari seorang padri berbangsa Prancis yaitu Yoseph Francis Lafitau (1600-1740). la mencoba membandingkan antara kebiasaan dan tata susila orang Indian yang hendak dinasranikan dengan adat istiadat bangsa Eropa kuno. Hasilnya, ia beranggapan bahwa bangsa primitif (Indian) tidak dilihatnya sebagai manusia yang aneh. Akan tetapi karena bahan yang diperbandingkannya sangat terbatas maka pandangannya tentang perbandingan ini pun sangat terbatas.

Ahli etnografi, dalam arti yang modern (Harsojo, 1984), adalah Jens Kreft, seorang guru besar pada akademi di Soro. la menulis sebuah buku berjudul "Sejarah Pendek tentang Lembaga-lembaga yang Terpenting, Adat dan Pandangan-pandangan Orang Liar" 1760. Jens Kreft awalnya adalah seorang ahli filsafat, di mana ia tidak sependapat dengan pandangan Pada jaman Romawi kuno terdapat pula beberapa hasil karya etnografi mengenai kehidupan suku bangsa Germania dan Galia yang ditulis oleh Tacitus dan Caesar. Sebagai seorang perwira yang memimpin perjalanan tentaranya sampai ke Eropa Barat, Caesar menulis etnografinya secara sistematis seperti halnya bentuk laporan seorang perwira. Sedangkan Tacitus menulis etnografinya dengan gaya bahasa yang mengungkap perasaan dan kegalauannya tentang kehidupan yang terdapat di ibukota kerajaan Roma. Pencatat etnografi yang cukup terkenal adalah Marco Polo (1254-1323). la mengembara dengan keluarga besarnya ke daerah Asia Timur dan sempat menetap di istana Khu Bilai Khan. Di sini ia melihat beberapa kebiasaan 
yang dianggapnya aneh, yaitu penggunaan uang yang terbuat dari kertas dan diberi cap serta ditandatangani di mana uang tersebut mempunyai bermacammacam nilai. Marco Polo juga pernah singgah di daratan Indonesia (yang diketahui dari tulisannya), di mana ia pernah singgah di beberapa pelabuhan dari semenanjung Malaya hingga menelusuri Pulau Sumatra, di antaranya adalah singgah ke di pelabuhan Perlec (dalam bahasa Aceh) atau Peureula atau Perlak (dalam bahasa Melayu). Marco Polo menceritakan kehidupan di kota pelabuhan ini di mana pedagang dari India dan penduduk pribuminya menganut agama Islam sedangkan penduduk yang ada di pedalaman masih mengerjakan hal-hal yang haram.

Tulisan etnografi yang dianggap lebih baik dan obyektif justru adalah buah tangan dari seorang padri berbangsa Prancis yaitu Yoseph Francis Lafitau (1600-1740). la mencoba membandingkan antara kebiasaan dan tata susila orang Indian yang hendak dinasranikan dengan adat istiadat bangsa Eropa kuno. Hasilnya, ia beranggapan bahwa bangsa primitif (Indian) tidak dilihatnya sebagai manusia yang aneh. Akan tetapi karena bahan yang diperbandingkannya sangat terbatas maka pandangannya tentang perbandingan ini pun sangat terbatas.

Ahli etnografi, dalam arti yang modern (Harsojo, 1984), adalah Jens Kreft, seorang guru besar pada akademi di Soro. la menulis sebuah buku berjudul "Sejarah Pendek tentang Lembaga-lembaga yang Terpenting, Adat dan Pandangan-pandangan Orang Liar" 1760. Jens Kreft awalnya adalah seorang ahli filsafat, di mana ia tidak sependapat dengan pandangan Rousseau tentang manusia. Pandangan Jens Kreft tentang manusia lebih dianggap mewakili pandangan sebagai seorang ahli etnologi daripada pandangan para ahli filsafat. Tulisan etnografinya adalah mengenai dua suku 
bangsa Indian, Lule dan Caingua, di Amerika Selatan, yang pada awalnya diduga mempunyai kebudayaan yang rendah. Ternyata dugaannya itu salah. la pun dipandang sebagai orang pertama yang menulis etnografi secara lengkap yaitu dengan memperhatikan aspek pertumbuhan ekonomi, masyarakat, agama dan kesenian.

Ahli berikutnya yang dianggap sebagai pendorong penulisan ilmiah dan sistematis mengenai etnografi adalah Adolf Bastian. la memberikan pandangan mengenai kesatuan kebudayaan yang dimiliki oleh suatu masyarakat, di mana suatu kebudayaan memiliki sifat-sifatnya yang khusus yang tumbuh dan berkembang sesuai dengan dasarnya dan lingkungannya. Penelitian secara ilmiah mengenai antropologi berkembang pesat setelah ditemukan atau setelah diketahui adanya hubungan antara bahasa Sansakerta, Latin, Yunani dan Germania (Harsojo, 1984), sehingga memungkinkan lebih banyak tersedia bahan-bahan etnografi sebagai bahan perbandingan. Atas dasar ini kemudian timbul penelitian yang bersifat historis komparatif mengenai kebudayaan. Dalam keperluan ini, berdirilah lembaga-lembaga etnologi seperti Museum Etnografi yang didirikan oleh G.J. Thomson di Kopenhagen tahun 1841, Museum Etnologi di Hamburg tahun 1850, The Peabody Museum of Archeology and Ethnology di Harvad tahun 1866, American Ethnological Society di New York tahun 1842, Ethnological Society of London di Inggris tahun 1843, dan The Bureau of American Ethnology di Amerika tahun 1875. Selama abad ke 20, penelitian antropologi dan etnologi makin berkembang, terutama di pusat-pusat kajian antropologi dan etnologi seperti di Amerika Serikat, Inggris, Afrika Selatan, Australia, Eropa Barat, Eropa Tengah, Eropa Utara, Uni Soviet dan Meksiko. Di Indonesia, bahan-bahan etnografi juga telah dikumpulkan terutama menyangkut adat istiadat, sistem 
kepercayaan, struktur sosial dan kesenian. Bahan-bahan etnografi tentang Indonesia banyak dikumpulkan oleh para pegawai pemerintah jajahan, di antaranya yang terkenal adalah T.S. Raffles mantan Letnan Gubernur Jenderal di Indonesia (antara tahun 1811 hingga 1815). Raffles banyak menulis kebudayaan penduduk pribumi Indonesia, di antaranya adalah dua jilid etnografi tentang kebudayaan Jawa.

\section{Ruang Lingkup Antropologi Hukum}

Antropologi sebagai salah satu cabang ilmu sosial mempunyai bidang kajian sendiri yang dapat dibedakan dengan ilmu sosial lainnya, seperti sosiologi, ilmu ekonomi, ilmu politik, kriminologi dan lain-lainnya.

Antropologi juga dapat dikelompokkan ke dalam cabang ilmu humaniora karena kajiannya yang terfokus kepada manusia dan kebudayaannya. Seperti halnya yang terjadi di Universitas Indonesia, di mana pada masa awal terbentuknya Jurusan Antropologi ini berada di bawah Fakultas Sastra. Akan tetapi dalam perkembangan selanjutnya, ketika muncul anggapan bahwa antropologi cenderung memiliki fokus pada masalah sosial dari keberadaan manusia, maka jurusan antropologi ini pun pada tahun 1983 pindah di bawah Fakultas IImu Sosial dan IImu Politik. Saat ini beberapa universitas di Indonesia mempunyai Jurusan Antropologi, di antaranya adalah di Universitas Padjadjaran (UNPAD), Universitas Gajah Mada (UGM), Universitas Andalas (Unand), Universitas Cendrawasih (Uncen), dan Universitas Udayana (Unud).

Sebagaimana sudah dijelaskan bahwa, secara umum dapat dikatakan antropologi merupakan ilmu yang mempelajari manusia dari segi keragaman fisiknya, masyarakatnya, dan kebudayaannya, namun demikian, di beberapa 
tempat, negara, dan universitas, antropologi sebagai ilmu mempunyai penekanan-penekanan tertentu sesuai dengan karakteristik antropologi itu sendiri dan perkembangan masyarakat di tempat, negara, dan universitas tersebut. Seperti yang pernah diungkapkan Koentjaraningrat bahwa ruang lingkup dan dasar antropologi belum mencapai kemantapan dan bentuk umum yang seragam di semua pusat ilmiah di dunia. Menurutnya, cara terbaik untuk mencapai pengertian akan hal itu adalah dengan mempelajari ilmu-ilmu yang menjadi pangkal dari antropologi, dan bagaimana garis besar proses perkembangan yang mengintegrasikan ilmu-ilmu pangkal tadi, serta mempelajari bagaimana penerapannya di beberapa negara yang berbeda.

Beberapa contoh menggenai perkembangan ruang lingkupn antropologi hukum yaitu:

\section{Manusia (bermasyarakat dalam hukum)}

Dalam antropologi ruang lingkup manusia (bermasyarakat) diantaranya perkembangan fisik. Dimana perkembangan fisik tertarik pada sisi fisik dari manusia. Termasuk didalamnya mempelajari gen-gen yang menentukan struktur dari tubuh manusia. Mereka melihat perkembangan mahluk manusia sejak manusia itu mulai ada di bumi sampai manusia yang ada sekarang ini. Beberapa ahli Antropologi Fisik menjadi terkenal dengan penemuan-penemuan fosil yang membantu memberikan keterangan mengenai perkembangan manusia. Ahli Antropologi Fisik yang lain menjadi terkenal karena keahlian forensiknya; mereka membantu dengan menyampaikan pendapat mereka pada sidang - sidang pengadilan dan membantu pihak berwenang dalam penyelidikan kasus-kasus pembunuhan.

Sedangkan ruang lingkup manusia khusus budaya (bermasyarakat) lebih mengarah tingkah laku manusia. Dimana dalam antropologi lebih sering disebut Antropologi Budaya berhubungan dengan apa yang sering disebut dengan Etnologi. Ilmu ini mempelajari tingkahlaku manusia, baik itu tingkah-laku individu atau tingkah laku kelompok. Tingkah-laku yang 
dipelajari disini bukan hanya kegiatan yang bisa diamati dengan mata saja, tetapi juga apa yang ada dalam pikiran mereka. Pada manusia, tingkah-laku ini tergantung pada proses pembelajaran. Apa yang mereka lakukan adalah hasil dari proses belajar yang dilakukan oleh manusia sepanjang hidupnya disadari atau tidak. Mereka mempelajari bagaimana bertingkahlaku ini dengan cara mencontoh atau belajar dari generasi diatasnya dan juga dari lingkungan alam dan social yang ada disekelilingnya. Inilah yang oleh para ahli Antropologi disebut dengan kebudayaan. Kebudayaan dari kelompok-kelompok manusia, baik itu kelompok kecil maupun kelompok yang sangat besar inilah yang menjadi objek spesial dari penelitian-penelitian Antropologi Sosial Budaya. Dalam perkembangannya Antropologi Sosial-Budaya ini memecah lagi kedalam bentuk-bentuk spesialisasi atau pengkhususan disesuaikan dengan bidang kajian yang dipelajari atau diteliti. Antroplogi Hukum yang mempelajari bentuk-bentuk hukum pada kelompok-kelompok masyarakat atau Antropologi Ekonomi yang mempelajari gejala-gejala serta bentuk-bentuk perekonomian pada kelompok-kelompok masyarakat adalah dua contoh dari sekian banyak bentuk spesialasi dalam Antropologi Sosial-Budaya.

\section{Kebudayaan}

Kata Kebudayaan atau budaya adalah kata yang sering dikaitkan dengan antropologi Secara pasti, Antropologi tidak mempunyai hak eksklusif untuk menggunakan istilah ini. Seniman seperti penari atau pelukis dll juga memakai istilah ini atau diasosiasikan dengan istilah ini Konsep ini memang sangat sering digunakan oleh Antropologi dan telah tersebar kemasyarakat luas bahwa Antropologi bekerja atau meneliti apa yang sering disebut dengan kebudayaan. Seringnya istilah ini digunakan oleh Antropologi dalam pekerjaan-pekerjaannya bukan berarti para ahli Antropolgi mempunyai pengertian yang sama tentang istilah tersebut Seorang Ahli Antropologi yang mencoba mengumpulkan definisi yang pernah dibuat, mengatakan: "Kebudayaan adalah seluruh cara kehidupan dari masyarakat dan tidak hanya mengenai sebagian tata cara hidup saja yang dianggap lebih tinggi dan lebih diinginkan". 
Selain itu Kebudayaan merupakan hasil budi daya manusia, ada yang mendefinisikan sebagai semua hasil karya, rasa dan cipta masyarakat. Karya manusia menghasilkan teknologi dan kebudayaan kebendaan, sedangkan rasa mewujudkan segala norma dan nilai untuk mengatur kehidupan dan selanjutnya cipta merupakan kemampuan berpikir kemampuan mental yang menghasilkan filsafat dan ilmu pengetahuan.Jadi, kebudayaan menunjuk pada berbagai aspek kehidupan. Istilah ini meliputi cara-cara berlaku, kepercayaan-kepercayaan dan sikap-sikap, dan juga hasil dari kegiatan manusia yang khas untuk suatu masyarakat atau kelompok penduduk tertentu.Pembatasan kebudayaan itu sendiri biasanya tidak selalu dirasakan oleh para pendukung suatu kebudayaan. Hal ini terjadi karena individu-individu pendukungnya selalu mengikuti cara-cara berlaku dan cara berpikir yang telah dituntut oleh kebudayaan itu. Pembatasan-pembatasan kebudayaan baru terasa kekuatannya ketika dia ditentang atau dilawan. Pembatasan kebudayaan terbagi kedalam 2 jenis yaitu pembatasan kebudayaan yang langsung dan pembatasan kebudayaan yang tidak langsung. Pembatasan langsung terjadi ketika kita mencoba melakukan suatu hal yang menurut kebiasaan dalam kebudayaan kita merupakan hal yang tidak lazim atau bahkan hal yang dianggap melanggar tata kesopanan atau yang ada.Akan ada sindiran atau ejekan yang dialamatkan kepada sipelanggar kalau hal yang dilakukannya masih dianggap tidak terlalu berlawanan dengan kebiasaan yang ada, akan tetapi apabila hal yang dilakukannya tersebut sudah dianggap melanggar tata-tertib yang berlaku dimasyarakatnya, maka dia mungkin akan dihukum dengan aturan-aturan yang berlaku dalam masyarakatnya. Contoh dari pembatasan langsung misalnya ketika seseorang melakukan kegiatan seperti berpakaian yang tidak pantas kedalam masjid. Ada sejumlah aturan dalam setiap kebudayaan yang mengatur tentang hal ini. Kalau si individu tersebut hanya tidak mengenakan baju saja ketika ke masjid, mungkin dia hanya akan disindir atau ditegur dengan pelan. oleh pihak-pihak tertentu karena dianggap mengganggu ketertiban umum. Dalam pembatasan-pembatasan tidak langsung, aktifitas yang dilakukan oleh orang yang melanggar tidak dihalangi atau dibatasi secara langsung akan tetapi kegiatan tersebut tidak akan 
mendapat respons atau tanggapan dari anggota kebudayaan yang lain karena tindakan tersebut tidak dipahami atau dimengerti oleh mereka.

Hukum (menurut antropologi) mempelajari hubungan perilaku manusia dengan system atau budaya diantaranya:

Nilai : Kumpulan atau himpunan tingkah laku baik dan buruk

Norma $\quad$ : Ukuran Sikap atau perilaku wajar atau menyimpang

Kaidah : Dalil atau rumusan juga dapat diartikan sebagai keseluruhan nilai, norma.

Kebiasaan : Atau kata lain aturan yang berasal dari hukum tradisional dan hukum modern

Hal ini karena para ahli antropologi mempelajari hukum bukan semata-semata sebagai produksi dari hasil abstraksi logika sekelompok orang yang diformulasikan dalam bentuk peraturan perundang-undangan, tetapi lebih mempelajari hukum sebagai perilaku social. Hukum dalam perspektif antropologi dipelajari sebagai bagian yang integral dari kebudayaan secara keseluruhan, dan karena itu hukum dipelajari sebagai produk dari interaksi sosial yang dipengaruhi oleh aspek-aspek kebudayaan yang lain, seperti politik, ekonomi, ideologi, religi, dIl. atau hukum dipelajari sebagai proses sosial yang berlangsung dalam kehidupan masyarakat. Karena itu, hukum dalam perspektif antropologi bukan semata-mata berwujud peraturan perundang-undangan yang diciptakan oleh Negara (state law), tetapi juga hukum dalam wujudnya sebagai peraturan-peraturan lokal yang bersumber dari suatu kebiasaan masyarakat (customary law/folk law), termasuk pula di dalamnya mekanisme-mekansime pengaturan dalam masyarakat (self regulation) yang juga berfungsi sebagai sarana pengendalian sosial (legal order). 


\section{Masyarakat (Tunggal Atau Penduduk satu daerah)}

Penduduk, masyarakat dan kebudayaan adalah konsep-konsep yang pertautannya satu sama lain sangat berdekatan. Bermukimnya penduduk dalam suatu wilayah tertentu dalam waktu yang tertentu pula, memungkinkan untuk terbentuknya masyarakat di wilayah tersebut. Ini berarti masyarakat akan terbentuk bila ada penduduknya sehinggat idak mungkin akan ada masyarakat tanpa penduduk, masyarakat terbentuk karena penduduk. Sudah barang tentu penduduk disini yang dimaksud adalah kelompok manusia, bukan penduduk/populai dalam pengertian umum yang mengandung arti kelompok organisme yang sejenis yang hidup dan berkembang biak pada suatu daerah tertentu.

Demikian pula hubungan antara masyarakat dan kebudayaan, ini merupakan dwi tunggal, hubungan dua yang satu dalam arti bahwa kebudayaan merukan hasil dari suatu masyarakat, kebudayaan hanya akan bisa lahir, tumbuh dan berkembang dalam masyarakat. Tetapi juga sebaliknya tidak ada suatu masyarakat yang tidak didukung oleh kebudayaan. Hubungan antara masyarakat dan kebudayaan inipun merupakan juga hubungan yang saling menentukan.Penduduk, dalam pengertian luas diartikan sebagai kelompok organisme sejenis yang berkembang biak dalam suatu daerah tetentu. Penduduk dalam arti luas itu sering diistilahkan popuasi dan disini dapat meliputi populais hewan, tumbuhan dan juga manusia. Dalam kesempatan ini penduduk digunakan dalam pengertian orang-orang yang mendiami wilayah tertentu, menetap dalam suatu wilayah, tumbuh dan berkembang dalam wilayah tertentu pula.Adapun masyarakat adalah suatu kesatuan kehidupan sosial manusia yang menempati wilayah tertentu, yang keteraturannya dalam kehidupan sosialnya telah dimungkinkan karena memiliki pranata sosial yang telah menjadi tradisi dan mengatur kehidupannya. Tekanannya disini terletak pada adanya pranata sosia, tanpa pranata sosial kehidupan bersama didalam masyarakat tidak mungkin dilakukan secara teratur. Pranata sosial disini dimaksudkan sebagai perangkat peraturan yang mengatur peranan serta hubungan antar anggota masyarakat, baik secara perseorangan maupun secara kelompok. 


\section{PENUTUP}

Antropologi merupakan sebuah ilmu yang mempelajari umat manusia (anthropos). Secara etimologi, antropologi berasal dari kata anthropos berarti manusia dan logos berarti ilmu. Antropologi memandang manusia sebagai sesuatu yang kompleks dari segi fisik, emosi, sosial, dan kebudayaannya. Antropologi sering pula disebut sebagai ilmu tentang manusia dan kebudayaannya. Antropologi mulai dikenal banyak orang sebagai sebuah ilmu setelah diselenggarakannya simposium International Symposium on Anthropologi pada tahun 1951, yang dihadiri oleh lebih dari 60 tokoh antropologi dari negara-negara di kawasan EroAmerika dan Uni Soviet.Simposium ini menghasilkan buku antropologi berjudul "Anthropology Today” yang di redaksi oleh A.R. Kroeber (1953), "An Appraisal of Anthropology Today” yang di redaksi oleh S. Tax, dkk. (1954), "Yearbook of Anthropology" yang di redaksi oleh W.L. Thomas Jr. (1955), dan “Current Anthropology” yang di redaksi oleh W.L. Thomas Jr. (1956). Setelah simposium ini, di beberapa wilayah berkembang pemikiran-pemikiran antropologi yang bersifat teoritis, sedangkan di wilayah yang lain antropologi berkembang dalam tataran fungsi praktisnya.

Beberapa contoh menggenai perkembangan ruang lingkupn antropologi hukum yaitu: 1.Manusia (bermasyarakat dalam hukum),2.Kebudayaan dan,3.Masyarakat (Tunggal Atau Penduduk satu daerah). Antropologi pada masa perkembangan awalnya tidak dapat dipisahkan dengan karya-karya para penulis yang mencatat gambaran kehidupan penduduk atau suku bangsa di luar Eropa. Pada saat itu, kehidupan penduduk di luar Eropa dipandang menarik oleh para penjelajah, para penjajah, atau para misionaris karena perbedaan cara hidup antara masyarakat Eropa dengan masyarakat di luar Eropa. Oleh karenanya, mereka bukan saja menulis tentang perjalanan atau yang terkait dengan tugasnya tetapi juga melengkapinya dengan deskripsi tentang tata cara kehidupan masyarakat yang mereka temui. 


\section{D.DAFTAR PUSTAKA}

Darmini Roza dan Laurensius Arliman S, Peran Pemerintah Daerah Di Dalam Melindungi Hak Anak Di Indonesia, Masalah-Masalah Hukum, Volume 47, Nomor 1, 2018. https://doi.org/10.14710/mmh.47.1.2018.10-21

Laurensius Arliman S, Peranan Metodologi Penelitian Hukum di Dalam Perkembangan Ilmu Hukum di Indonesia, Soumatera Law Review, Volume 1, Nomor 1, 201. http://doi.org/10.22216/soumlaw.v1i1.3346.

Laurensius Arliman S, Peran Badan Permusyawaratan Desa di Dalam Pembangunan Desa dan Pengawasan Keuangan Desa, Padjadjaran Journal of Law, Volume 4, Nomor 3, 2017. https://doi.org/10.15408/jch.v4i2.3433.

Laurensius Arliman S, Penanaman Modal Asing Di Sumatera Barat Berdasarkan Undang- Undang Nomor 25 Tahun 2007 Tentang Penanaman Modal, Supremasi Hukum, Volume 1, Nomor 1, 2018. http://dx.doi.org/10.36441/hukum.v1i01.102.

Laurensius Arliman S, Memperkuat Kearifan Lokal Untuk Menangkal Intoleransi Umat Beragama Di Indonesia, Ensiklopedia of Journal, Volume 1, Nomor 1, 2018, https://doi.org/10.33559/eoj.v1i1.18.

Laurensius Arliman S, Perkawinan Antar Negara Di Indonesia Berdasarkan Hukum Perdata Internasional, Kertha Patrika, Volume 39, Nomor 3, 2017,https://doi.org/10.24843/KP.2017.v39.i03.p03.

Laurensius Arliman S, Partisipasi Masyarakat Di Dalam Pengelolaan Uang Desa PascaUndang-Undang Nomor 6 Tahun 2014 Tentang Desa, Jurnal Arena Hukum, Volume 12, Nomor 2, 2019, https://doi.org/10.21776/ub.arenahukum.2019.01202.5.

Laurensius Arliman S, Mewujudkan Penegakan Hukum Yang Baik Di Negara Hukum Indonesia, Dialogica Jurnalica, Volume 11, Nomor 1, 2019, https://doi.org/10.28932/di.v11i1.1831.

Laurensius Arliman S, Mediasi Melalui Pendekatan Mufakat Sebagai Lembaga Alternatif Penyelesaian Sengketa Untuk Mendukung Pembangunan Ekonomi Nasional, UIR Law Review, Volume 2, Nomor 2, 2018, https://doi.org/10.25299/uirlrev.2018.vol2(02).1587

Laurensius Arliman S, Peranan Filsafat Hukum Dalam Perlindungan Hak Anak Yang Berkelanjutan Sebagai Bagian Dari Hak Asasi Manusia, Doctrinal, Volume 1, Nomor 2,2016.

Laurensius Arliman S, Ni Putu Eka Dewi, Protection of Children and Women's Rights in Indonesia through International Regulation Ratification, Journal of Innovation, Creativity and Change Volume 15, Nomor 6, 2021.

Laurensius Arliman S, Gagalnya Perlindungan Anak Sebagai Salah Satu Bagian Dari Hak Asasi Manusia Oleh Orang Tua Ditinjau Dari Mazhab Utilitarianisme, Jurnal Yuridis, Volume 3, Nomor 2, 2016, http://dx.doi.org/10.35586/.v3i2.180. 
